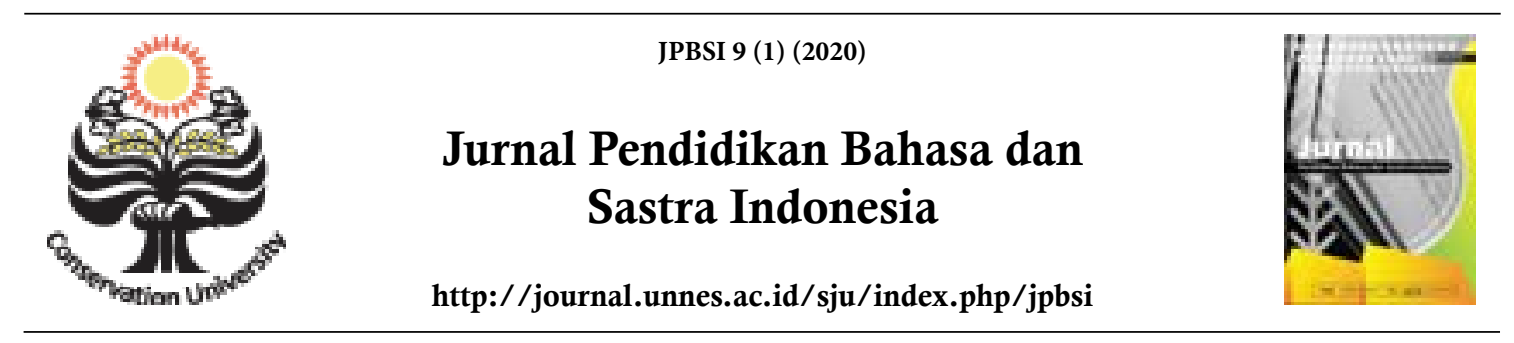

\title{
IMPLEMENTASI TRI-N (NITENI-NIROKKE-NAMBAHI) DAN PPK (PENGUATAN PENDIDIKAN KARAKTER) PADA PERANGKAT PEMBELAJARAN TEKS DESKRIPSI KELAS VII SMP
}

\author{
Ermawati $\bowtie$ Siti Rochmiyati
}

Fakultas Keguruan dan Ilmu Pendidikan, Universitas Sarjanawiyata Tamansiswa Yogyakarta, Indonesia

\section{Info Artikel}

Sejarah Artikel:

Diterima November 2019

Disetujui April 2020

Dipublikasikan Mei 2020

Keywords:

Description text, Tri-N, $P P K$

\begin{abstract}
Abstrak
Penelitian ini bertujuan untuk mendeskripsikan pengembangan Tri-N (Niteni-Nirokke-Nambahi) dan Penguatan Pendidikan Karakter (PPK) dalam perangkat pembelajaran teks deskripsi kelas VII di SMP. Perangkat pembelajaran tersebut adalah berupa Rencana Pelaksanaan Pembelajaran (RPP). RPP memuat ajaran Tri-N dan PPK diimplementasikan di bagian kegiatan proses pembelajaran yaitu di pendahuluan, kegiatan inti, dan kegiatan penutup. Tri-N ditunjukkan dalam kegiatan niteni-mengamati, niteni-menanya, niteni-mengasosiasi, nirokke-mengasosiasi, nambahi-mendesain, dan nambahi-mencipta. PPK yang dimuat di dalam perangkat pembelajaran RPP teks deskripsi ini meliputi religius, disiplin, percaya diri, kerja sama, dan mandiri.
\end{abstract}

\begin{abstract}
This study aims to describe the development of Tri-N (Niteni-Nirokke-Nambahi) and Strengthening Character Education (PPK) in the VII grade text description learning tool in junior high schools. The learning kit is in the form of a Learning Implementation Plan (RPP). The RPP contains the teachings of Tri-N and PPK implemented in the learning process activities section, namely in the introduction, core activities, and closing activities. Tri-N is shown in the activities of niteni-observing, niteni-asking, niteni-associating, nirokke-associating, nambahi-designed, and nambahi-creation. PPK that is contained in the lesson plan lesson text description includes religious, disciplined, confident, cooperative, and independent.
\end{abstract}




\section{PENDAHULUAN}

Pendidik dan peserta didik merupakan dua komponen penting di dalam pembelajaran. Pendidik pada umumnya telah melakukan penyusunan program pembelajaran yang di dalamnya terdapat prosedur pelaksanaan. Lebih lanjut diungkapkan dalam tulisan sebelumnya pelaksanaan pembelajaran lebih terprosedur jika perencaanaan disusun secara mantap, dengan kata lain perencanaan berhubungan dengan pelaksanaan (Ermawati, 2019: 2). Di dalam prosedur pembelajaran memuat beberapa hal mencakup komponen pembelajaran. Komponen pembelajaran di antaranya, yaitu tujuan pembelajaran, materi pembelajaran, metode pembelajaran, media pembelajaran, evaluasi pembelajaran, peserta didik, dan pendidik. Rencana Pelaksanaan Pembelajaran (RPP) merupakan salah satu perangkat pembelajaran yang di dalamnya memuat sejumlah komponen pembelajaran tersebut.

Berdasarkan wawancara yang dilakukan kepada seorang pendidik, ditemukan permasalahan yaitu pendidik membutuhkan waktu khusus dalam mempersiapkan Rencana Pelaksanaan Pembelajaran (RPP). Beberapa pendidik mengungkapkan yang terpenting adalah pelaksanaan pembelajaran. Akan tetapi, pembelajaran akan lebih optimal bila direncanakan secara matang terlebih pada bagian prosedur pembelajaran.

Salah satu komponen pembelajaran yang eksplisit di dalam langkah kegiatan pembelajaran adalah model pembelajaran. Didukung dengan pendapat Rochmiyati dan Mukhlis (2018: 290) yang mengungkapkan guru harus menerapkan model-model pembelajaran yang inovatif dan mengutamakan pembentukan karakter siswa. Muara akhir pembelajaran menjuju pada pembentukan karakter melalui pendidikan karakter memang penting, seperti data yang dihimpun oleh Ermawati (2017: 213), pada penelitian sebelumnya menunjukkan potret pendidikan yang disajikan di media masa akhir-akhir ini, mengajak masyarakat untuk berrefleksi, berjiwa sosial, dan berempati. Untuk itu, tuntunan penggunaan model pembelajaran yang inovatif harusnya tercermin dalam RPP yang direncanakan oleh guru dan yang diimplementasikan dalam Kegiatan Belajar Mengajar (KBM). Begitupun dengan pilar pendidikan karakter yang dimulai dari lembaga pendidikan sebaiknya tersurat di dalam pembelajaran.

Model pembelajaran diperlukan sebagai untur mengatur dan memberi petunjuk arah proses pembelajaran. Seperti yang diungkapkan oleh Abidin (2016: 116) model pembelajaran sebenarnya adalah wadah bagi pendekatan, me- tode, dan teknik pembelajaran sebagai pedoman perbaikan kegiatan belajar mengajar. Ki Hadjar Dewantara sebagai pendiri Tamansiswa memiliki model pembelajaran berbasis Tri-N (Niteni, Nirokke, Nambahi). Pendekatan dalam kurikulum 2013 berhubungan erat dengan konsep Tri-N. Pernyataan tersebut sependapat dengan Prihatni (2014: 300) yang memaparkan ajaran Ki Hadjar Dewantara (KHD) mempunyai relevansi dengan kegiatan pembelajaran saat ini, sebagai tolak ukur antara lain: konsep Tri Nga (Ngerti, Ngroso, Nglakoni) yang diselaraskan dengan kognitif, sikap (afektif), dan psikomotorik. Sesuai dengan penelitian yang dilakukan oleh Rahayu dan Siti Rochmiyati (2019) telah membuktikan bahwa model Tri_N (niteni-nirokke-nambahi) terdapat di buku pegangan siswa kelas VIII SMP.

Oleh karena itu, diperlukan pengembangan lebih lanjut mengenai perangkat pembelajaran berbasis Tri-N untuk meningkatkan perkembangan keaktifan siswa dalam proses pembelajaran. Berdasarkan latar belakang masalah yang diuraikan sebelumnya, dirumuskan tujuan penelitian ini adalah untuk mendeskripsikan dan menjelaskan penerapan ajaran Tri-N (niteni, nirokke, nambahi) dan PPK pada perangkat pembelajaran teks deskripsi di Sekolah Menengah Pertama.

Seperangkat teori Tri- $N$ yang dihasilkan dari penelitian bersama Damayanti dan Siti Rochmiyati (2019: 388) memaparkan niteni adalah menandai dengan menggunakan seluruh pancaindera secara seksama. Nirokke adalah menirukan apa yang diajarkan melalui model/contoh / teladan dari guru/sumber belajar dengan melibatkan pikiran, penginderaan, perasaan/nurani dan spiritual secara integral dan harmonis. Melalui proses melafalkan/melalui suara; menirukan dengan membaca, menirukan dengan menulis, menirukan melalui gerakan, menirukan dengan mencoba/eksperimen, menirukan dengan mendemonstrasikan atau mempraktikkan, menirukan dengan menyajikan. Nambahi adalah menambah apa yang telah dipelajari melalui model/contoh/ teladan dari guru/sumber belajar dengan mengembangkan kreativitas dan gagasannya. Melalui proses: menambahi dengan mendesain, menambahi dengan mencipta/membuat, menambahi dengan mengimprovisasi.

\section{METODE}

Penelitian ini adalah penelitian payung yang dilakukan antara dosen dan mahasiswa. Jenis penelitian yang dilakukan adalah penelitian pengembangan atau Research and Development (R\&D). Penelitian pengembangan produk perangkat pembelajaran dilaksanakan pada 
kelas VII di SMP Negeri 11 Yogyakarta yang beralamat di J1. HOS Cokroaminoto No. 127, Tegalrejo, Kecamatan Tegalrejo, Kota Istimewa Yogyakarta 55231. Alasan dipilih tempat penelitian pengembangan perangkat pembelajaran karena telah menerapkan kurikulum 2013 dalam pembelajaran. Penelitian ini dilaksanakan selama semester genap tahun pelajaran 2018/2019. Sumber data dalam penelitian ini adalah hasil penelitian Anastasia Rina Afridaningrum (2018) berjudul "Pengembangan Perangkat Pembelajaran Teks Deskripsi Berbasis Tri-N pada Siswa Kelas VII di SMP Negeri 11 Yogyakarta tahun pelajaran 2018/2019". Data penelitian ini adalah komponen kegiatan pembelajaran pada RPP Teks Deskripsi Berbasis Tri-N Kelas VII di SMP Negeri 11 Yogyakarta.

\section{HASIL DAN PEMBAHASAN}

Produk RPP merupakan hasil dari penelitian payung dengan mahasiswa Anastasia Rina Afridaningrum (2018). RPP terdiri atas empat pertemuan dengan alokasi waktu sebanyak $3 \mathrm{JP}$ per pertemuan. Komponen RPP pada kegiatan pembelajaran terdiri atas kegiatan awal, kegiatan inti, dan kegiatan penutup. Implementasi Tri_N dan PPK pada KD 3.1, 4.1, 3.2, 4. 2 kelas VII sebagai berikut.

\section{Pendahuluan}

Peserta didik bersama guru berdoa secara khusyuk dan penuh rasa syukur dengan dipimpin salah satu peserta didik sebelum kegiatan pembelajaran dimulai. Setelah itu, peserta didik menjawab salam dari guru (PPK-Religius) (A1). Kehadiran peserta didik didata oleh guru (A2). Peserta didik mempersiapkan kelas sebelum belajar (kerapian berpakaian dan posisi tempat duduk). Kemudian peserta didik diajak untuk mengkondisikan suasana belajar yang menyenangkan (saling bertukar kabar) (A3). Peserta didik mendengarkan penjelasan indikator dan kompetensi pembelajaran yang disampaikan oleh guru ( $\mathrm{Ni}$ teni- Mengamati) (A4). Peserta didik menyimak apersepsi yang diberikan oleh guru tentang teks deskripsi (Niteni- Mengamati) (A5). Peserta didik bertanya jawab mengenai materi yang akan diberikan (Niteni- Menanya) (A6). Peserta didik bersama guru menyepakati langkah-langkah kegiatan yang akan dilaksanakan untuk mencapai kompetensi (A7).

\section{Kegiatan Inti Pertemuan I}

Peserta didik mengamati menggunakan indera penglihatan dengan saksama contoh teks deskripsi yang berjudul "Pantai Kuta Bali" (Ni-
teni-Mengamati) (I.1.1). Peserta didik mengamati menggunakan indera pendengaran dengan seksama materi teks deskripsi yang disampaikan guru (Niteni-Mengamati) (I.1.2). Peserta didik menggali informasi lebih dalam dari hasil pengamatan yang sudah diamati (Niteni- Menanya) (I.1.3). Peserta didik secara individu (mandiri) menirukan dengan melafalkan atau melalui suara menjelaskan mengenai pengertian dan menyebutkan tujuan, ciri-ciri, serta macam-macam teks deskripsi berdasarkan materi yang telah diamati (Nirokke-Mengasosiasikan) (I. 1.4). Peserta didik menalar hasil penggalian pengetahuan yang sudah dimiliki dengan menyampaikan pertanyaan-pertanyaan berkaitan dengan hal-hal yang berhubungan dengan contoh teks deskripsi "Pantai Kuta Bali" yang diberikan oleh guru (NiteniMenalar) (I. 1.5). Peserta didik bersama guru membahas pertanyaan-pertanyaan yang berkaitan dengan contoh teks deskripsi "Pantai Kuta Bali" (I. 1.6). Peserta didik berdiskusi dengan teman sebangku untuk mengidentifikasi ciri dan tujuan teks deskripsi yang berjudul "Pantai Kuta Bali" (I. 1.6). Peserta didik secara lisan mempresentasikan dengan rasa percaya diri hasil dari kerja kelompok sesuai pemahamannya (I.1.7). Peserta didik bersama guru menyimpulkan hasil pembelajaran yang telah diterima (Niteni-Menalar) (I.1.8).

\section{Kegiatan Inti Pertemuan II (3 JP)}

Peserta didik mengamati menggunakan indera pendengaran contoh teks deskripsi "Sekolahku" yang dibacakan oleh salah satu peserta didik (Niteni- Mengamati) (I.2.1). Guru membimbing peserta didik menggali informasi lebih dalam dari hasil pengamatan dengan melakukan tanya jawab mengenai teks deskripsi yang telah didengar (Niteni- Menanya) (I.2.2). Peserta didik mengamati menggunakan indera penglihatan tentang struktur dan penggunaan bahasa dari contoh-contoh teks deskripsi yang disediakan guru (Niteni- Mengamati) (I.2.3). Peserta didik menirukan dengan membaca/menulis tentang struktur dan penggunaan bahasa teks deskripsi yang disampaikan guru (Nirokke- Mengasosiasikan) (I.2.4). Peserta didik secara berkelompok menelaah struktur dan penggunaan bahasa dalam teks deskripsi yang sudah disediakan (I.2.5). Peserta didik menuliskan hasil diskusi kelompok dalam bentuk laporan pada selembar kertas (I.2.6). Peserta didik mempresentasikan hasil kerja kelompoknya (I.2.7). Peserta didik bersama guru menyimpulkan hasil diskusi mengenai struktur dan penggunaan bahasa teks deskripsi yang baik (I. 2. 8). 


\section{Kegiatan Inti Pertemuan III}

Peserta didik mengamati menggunakan indera pendengaran teks deskripsi yang berjudul "Candi Borobudur" yang dibacakan salah satu peserta didik (Niteni- Mengamati) (I.3.1). Peserta didik menggali informasi lebih dalam dari hasil pengamatan dengan melakukan tanya jawab mengenai teks deskripsi yang telah didengar (Niteni-Menanya) (I.3.2). Peserta didik mengamati menggunakan indera penglihatan isi dari teks deskripsi yang berjudul "Candi Borobudur" yang sudah disediakan guru (Niteni-Mengamati) (I.3.3). Peserta didik menggali informasi lebih dalam dari hasil pengamatan isi teks deskripsi yang berjudul "Candi Borobudur" yang sudah disediakan guru (Niteni-Menanya) (I.3.4). Peserta didik secara berkelompok menentukan isi teks deskripsi yang sudah disediakan guru (I.3.5) (PPK-gotongroyong). Peserta didik menuliskan hasil diskusi kelompok dalam bentuk laporan pada selembar kertas (I.3.6). Peserta didik secara berkelompok menambahi dengan mendesain pemetaan isi teks deskripsi yang berjudul "Candi Borobudur" yang disediakan guru (NambahiMendesain) (I.3.7). Peserta didik bersama guru menyimpulkan hasil diskusi mengenai isi dan pemetaan isi dalam teks deskripsi yang sudah disediakan (I.3.8).

\section{Kegiatan Inti Pertemuan IV (3 JP)}

Peserta didik diputarkan video tentang teks deskripsi tentang objek sekolah oleh guru (I.4.1). Peserta didik mengamati menggunakan indera penglihatan dan indera pendengaran mengenai video teks deskripsi yang diputarkan guru (Niteni-Mengamati) (I.4.2). Peserta didik menirukan dengan mencoba/eksperimen membuat teks deskripsi tentang objek sekolah (NirokkeMengasosiasikan) (I.4.3). Peserta didik secara individu (mandiri) menambahi dengan mencipta teks deskripsi tentang objek sekolah (NambahiMenciptakan) (I.4.4) (PPK-Mandiri). Peserta didik menuliskan hasil kerjanya dalam bentuk laporan selembar kertas (I.4.5). Salah satu peserta didik mempresentasikan hasil kerjanya (I.4.6). Peserta didik yang lain diberi kesempatan untuk bertanya atau menyampaikan (I.4.7).

\section{Kegiatan Penutup}

Peserta didik bersama guru menyimpulkan hasil pembelajaran (Niteni-Menalar) (P.1). Peserta didik bersama guru mengevaluasi hasil pembelajaran (P.2). Peserta didik diberi tindak lanjut (penugasan) yaitu mempelajari materi pada pertemuan berikutnya (P.3). Peserta didik mendengarkan rencana pembelajaran berikutnya yang disampaikan oleh guru (Niteni-Mengamati) (P.4). Peserta didik bersama guru mengakhiri kegiatan pembelajaran dengan berdoa dan salam (P.5).

Berdasarkan data di atas, implementasi Tri-N pada teks deskripsi sudah tercermin di kegiatan awal yaitu kegiatan niteni-mengamati dan niteni-menanya. Berdasarkan data pula terdapat kegiatan peserta didik mendengarkan penjelasan indikator dan kompetensi pembelajaran yang disampaikan oleh guru (Niteni-Mengamati) (A4). Peserta didik menyimak apersepsi yang diberikan oleh guru tentang teks deskripsi (NiteniMengamati) (A5). Peserta didik bertanya jawab mengenai materi yang akan diberikan (NiteniMenanya) (A6).

Dalam kegiatan inti I, Tri-N ditunjukkan dalam kegiatan niteni-mengamati, niteni-menanya, nirokke-mengasosiasikan, niteni-menalar. Hal tersebut dipaparkan dalam kegiatan inti I berikut ini. Peserta didik mengamati contoh teks deskripsi yang berjudul "Pantai Kuta Bali" (Niteni-Mengamati) (I.1.1). Peserta didik mengamati materi teks deskripsi (Niteni-Mengamati) (I.1.2). Peserta didik menggali informasi (NiteniMenanya) (I.1.3). Peserta didik secara individu (mandiri) menirukan pengertian dan menyebutkan tujuan, ciri-ciri, serta macam-macam teks deskripsi (Nirokke-Mengasosiasikan) (I. 1.4). Peserta didik menalar hasil penggalian pengetahuan yang sudah dimiliki (Niteni-Menalar) (I. 1.5). Peserta didik bersama guru menyimpulkan hasil pembelajaran (Niteni-Menalar) (I.1.8).

Dalam kegiatan inti II, Tri-N ditunjukkan dalam kegiatan niteni-mengamati, nitenimenanya, nirokke-mengasosiasi. Hal tersebut dipaparkan dalam kegiatan inti II berikut. Peserta didik mengamati menggunakan indera pendengaran contoh teks deskripsi "Sekolahku" (NiteniMengamati) (I.2.1). Guru membimbing peserta didik menggali informasi lebih dalam dari hasil pengamatan dengan melakukan tanya jawab ( $\mathrm{Ni}$ teni- Menanya) (I.2.2). Peserta didik mengamati struktur dan penggunaan bahasa teks deskripsi (Niteni-Mengamati) (I.2.3). Peserta didik menirukan dengan membaca/menulis tentang struktur dan penggunaan bahasa teks deskripsi yang disampaikan guru (Nirokke- Mengasosiasikan) (I.2.4).

Dalam kegiatan inti III, Tri-N ditunjukkan dalam kegiatan niteni-mengamati, niteni-menanya, nambahi mendesain. Hal tersebut dipaparkan dalam kegiatan inti III berikut. Peserta didik mengamati menggunakan teks deskripsi" Candi Borobudur" (Niteni-Mengamati) (I.3.1). Peserta didik menggali informasi mengenai teks deskripsi 
(Niteni-Menanya) (I.3.2). Peserta didik mengamati isi dari teks deskripsi (Niteni- Mengamati) (I.3.3). Peserta didik menggali informasi (NiteniMenanya) (I.3.4). Peserta didik secara berkelompok menambahi dengan mendesain pemetaan isi teks deskripsi (Nambahi-Mendesain) (I.3.7).

Dalam Kegiatan Inti IV, Tri-N ditunjukkan dalam kegiatan niteni-mengamati, nitenimengasosiasi, nirokke-mengasosiakan, nambahi-mencipta. Hal tersebut dipaparkan dalam kegiatan inti IV berikut. Peserta didik mengamati menggunakan indera penglihatan dan indera pendengaran video teks deskripsi (Niteni- Mengamati) (I.4.2). Peserta didik menirukan dengan mencoba/eksperimen membuat teks deskripsi (Nirokke- Mengasosiasikan) (I.4.3). Peserta didik secara individu (mandiri) menambahi dengan mencipta teks deskripsi (Nambahi- Mencipta) (I.4.4).

Dalam kegiatan penutup, dipaparkan kegiatan Tri_N peserta didik niteni-menalar dan $n i$ teni-mengamati. Peserta didik bersama guru menyimpulkan hasil pembelajaran (Niteni-Menalar) (P.1). Peserta didik mendengarkan rencana pembelajaran berikutnya yang disampaikan oleh guru (Niteni- Mengamati) (P.4).

\section{Hasil Validasi dan Uji Coba}

Berdasarkan hasil penelitian di kelas VII SMP N 11 Yogyakarta, model pembelajaran kelas Tri-N terbukti dapat meningkatkan hasil rata-rata keterampilan menulis teks deskripsi. Uji coba lapangan nilai rata-rata siswa mencapai 75,25 , dengan kriteria tinggi (T). Pada saat uji coba lapangan produk akhir, hasil rata-rata keterampilan menulis teks deskripsi dengan Tri_N mencapai 85,25. Hasil uji coba tersebut dilakukan perbandingan dengan kelas guru khusus pada siswa kelas VII C dengan hasil rata-rata nilai siswa 68,5. Dengan demikian, kelas yang mengimplementasikan RPP berbasis Tri-N dan PPK lebih tinggi dibandingkan kelas guru. Oleh karena itu, dilihat dari segi proses pembelajaran Tri-N dapat meningkatkan aktivitas pembelajaran. Sejalan dengan pendapat Wijayanto (2019: 155) mengungkapkan Tr-N memberikan peluang siswa untuk mengalami proses dan menemukan konsep. Artinya, melalui model Tri_N, pendidik memberikan kesempatan untuk mengeksplorasi.

Hal tersebut didukung dengan hasil penelitian Nita, dkk (2017: 142) yang mengungkapkan Tri-N dapat mempengaruhi hasil belajar siswa dan kreativitas. Lebih lanjut dipaparkan, Tri-N sebaiknya dilakukan sesuai dengan tiga tahapan sebab tahapan tersebut berpengaruh terhadap pencapaian tujuan. Pendapat Nita didukung oleh penelitian Amalia, dkk (2017: 308) yang menyatakan melalui tiga tahapan kegiatan yaikni niteni-nirokke-nambahi diharapkan dapat meningkatkan keterampilan menulis puisi.

\section{PPK}

PPK yang terdapat dalam teks eksplanasi terdiri atas: PPK religius, disiplin, kerja sama, dan mandiri. Hal tersebut ditunjukkan dalam data berikut ini. Peserta didik bersama guru berdoa secara khusyuk dan penuh rasa syukur dengan dipimpin salah satu peserta didik sebelum kegiatan pembelajaran dimulai (PPK-Religius) (A1). Peserta didik dan guru menyepakati langkahlangkah pembelajaran mengenai kegiatan yang akan dilaksanakan untuk mencapai kompetensi pembelajaran (niteni-mengamati) (PPK-Disiplin) (A.5). Peserta didik secara berkelompok menentukan isi teks deskripsi yang sudah disediakan guru (I.3.5) (PPK-gotongroyong). Peserta didik secara individu (mandiri) menambahi dengan mencipta teks deskripsi tentang objek sekolah (Nambahi-Mencipta) (I.4.4) (PPK-Mandiri).

Berdasarkan data A.1., A.5, I.3.5 dan I.4.4., peserta didik diberikan penguatan karakter pada sikap religius, disiplin dalam mengerjakan tugas. Selain itu peserta didik diharapkan memiliki sikap sosial dengan cara bekerja sama dalam mengerjakan tugas. Di samping kerja sama atau gotong royong, peserta didik dibekali nilai karakter untuk bersikap mandiri pada saat menciptakan karya. Dengan demikian, PPK di dalam RPP ini memiliki kelebihan. Di samping, memperkuat sikap sosial peserta didik, peserta didik juga belajar bersikap mandiri. Sikap sosial tersebut terwujud ketika peserta didik juga menyajikan laporan dan mengimprovisasikan hasil karyanya dengan berkelompok merupakan wujud PPK kerja sama (gotong royong). Seperti penelitian yang dilakukan sebelumnya diungkapkapkan bahwa desain pembelajaran yang dibuat pendidik harus mempertimbangkan peran sosial, kedemokratisan, keahlian, multikulturan, dan regulasi (Ermawati dan Joko Santoso, 2018: 171). Slavin dalam Rusman (2012: 205) juga mengungkapkan penerapan pembelajaran kooepratif (kerja sama) dapat meningkatkan prestasi belajar siswa dan hubungan sosial, sikap sosial, dan menghargai pendapat orang lain. Untuk itu, PPK kerja sama yang berhubungan dengan sikap sosial dimunculkan dalam RPP ini. PPK sebaiknya muncul dan tercermin di dalam kegiatan akademik salah satunya melalui RPP yang disusun oleh pendidik maupun budaya sekolah. Pendapat tersebut sejalan dengan penjelasan Beland dalam Althof (2017: 510) pendidikan karakter harus menjadi bagian dari 
kegiatan akademik maupun kegiatan ekstra kurikuler dan semua aspek kehidupan sekolah seperti budaya sekolah.

\section{SIMPULAN}

Pertama, implementasi Tri-N dalam teks deskripsi meliputi: dalam kegiatan inti I, Tri-N ditunjukkan dalam kegiatan niteni-mengamati, niteni-menanya, niteni-mengasosiasi, nirokkemengasosiasi, dan nambahi mengomunikasikan. Hal tersebut dipaparkan dalam kegiatan inti II berikut. Bagian kegiatan inti II, implementasi Tri-N ditunjukkan dalam kegiatan niteni-mengamati, niteni-menanya, nirokke-mengasosiasi. Dalam kegiatan inti III, implementasi Tri-N ditunjukkan dalam kegiatan niteni-mengamati, niteni-menanya, nambahi mendesain. Dalam kegiatan inti IV, Tri-N ditunjukkan dalam kegiatan niteni-mengamati, niteni-mengasosiasi, nirokkemengasosiakan, nambahi-menciptakan. Kedua, PPK yang terdapat dalam teks eksplanasi terdiri atas: religius, disiplin, kerja sama, dan mandiri. PPK pada RPP ini memiliki kelebihan, peserta didik dapat bekerja secara mandiri maupun gotong-royong dengan tetap mengimplementasikan sikap religius dan disiplin.

\section{UCAPAN TERIMA KASIH}

Penelitian ini merupakan penelitian bersama yang dilakukan oleh beberapa mahasiswa. Salah satunya bersama mahasiswa Anastasia Rina Afridaningrum dengan NIM 2015001006 yang membahas pengembangan perangkat pembelajaran teks deskripsi kelas VII.

\section{REFERENSI}

Abidin, Yunus. 2016. Desain Pembelajaran dalam Konteks Kurikulum 2013. Bandung: PT Refika Aditama.

Althof Wolfgang dan Marvin W. Berkowitz. 2006. "Moral Education and Character Education: Their Relationship And Roles Cirizenship Education". Jounal of Moral Education. Vo. 35 No.4. USA: University of Missouri-St.Louis.

Afridaningrum, Anastasia Rina. 2019. "Pengembangan Perangkat Pembelajaran Teks Deskripsi Berbasis Tri-N pada Siswa Kelas VII di SMP Negeri 11 Yogyakarta tahun pelajaran 2018/2019". Skripsi. Yogyakarta: PBSI FKIP UST.

Amalia, Ika Fitri, Mai Istiqomatul Masluhah, Maria F. Fernandez. 2017. "Pengaruh Metode Pembelajaran 3N (Niteni, Nirokke, Nambahi) Terhadap Keterampilan Menulis Puisi pada Mata Pela- jaran Bahasa Indonesia Siswa Sekolah Dasar". Prosiding TEP \& P Ds. Tema 4. No. 20. Hlm 304-309. Surabaya: Pascasarjana Universitas Negeri Surabaya.

Damayanti, Siwi dan Siti Rochmiyati. 2018. "Telaah Penerapan Tri-N pada Buku Bahasa Indonesia Kelas IX SMP". Muara Pendidikan. Vo. 4. No. 2. Hlm. 388-397. Jambi: LP3M STKIP Muhammadiyah Muara Bungo.

Ermawati. 2017. "Integrasi Know-Want to KnowLearned-Affe (KWLA) dalam Pembelajaran teks Anekdot sebagai Penguatan Intrapersonal Intelligence". Wacana Akademika. Vol1. No.2. PP. 211-222. Universitas Sarjanawiyata Tamansiswa Yogyakarta: Fakultas Keguruan dan Ilmu Pendidikan.

Ermawati dan Joko Santoso. 2018. "Desain Pembelajaran Kelas Anti-Klithih". Junal Caraka. Vol.4. No.2. Pp.167-172. Universitas Sarjanawiyata Tamansiswa Yogyakarta: PBSI Fakultas Keguruan dan Ilmu Pendidikan.

Ermawati. 2019. "Pengembangan Assesment Pembeljaran Berbasis online Teks Deskripsi Mata Pelajaran Bahasa Indonesia SMP". Junal Caraka. Vol.6. No.1. Pp.1-16. Universitas Sarjanawiyata Tamansiswa Yogyakarta: PBSI Fakultas Keguruan dan Ilmu Pendidikan.

Nita, Cicilia Ika Rahayu, dkk. 2017. "Niteni, Nirokke, Nambahi (3N) Concept in the learning of Dance in Elementary School". Vol.5. No.5. Mediterranean Journal of Social Sciences.

Prihatni, Yuli. 2014. "Pendekatan Saintifik dalam Ajaran Ki Hadjar Dewantara". Prosiding Seminar Nasional Pendidikan. Yogyakarta: FKIP UST

Rahayu, Siti dan Siti Rochmiyati. 2019. "Penerapan Tri-N dalam Buku teks Siswa Bahasa Indonesia untuk Siswa SMP kelas VIII Kurikulum 2013". Silampari Bisa. Vo. 2. No.2. PP.173-184. Lubuklinggau: LP4MK STKIP PGRI Lubuklinggau.

Rochmiyati, Siti dan Mukhlish. 2018. "Pengembangan RPP dengan Model Cooperative Learning bagi Guru-Guru Bahasa Indonesia". Jurnal SOL$M A$. Vol. 7. No. 2. Yogyakarta: P B S I UST.

Rusman. 2012. Model-Model Pembelajaran. Jakarta: PT Raja Grafindo.

Wijayanto, Zainur. 2019. "Implementation of 3N (Niteni, Nirokke, Nambahi) In Stimulating Critical Thinking Ability". Proceeding Intercultural Collaboration Indonesia - Malaysia Implementation of Tamansiswa Philosophy'. Yogyakarta: UST. 